\title{
Leadership Networks as a Tool of Coercion in World Politics
}

\author{
A. Podberezkin, O. Podberezkina \\ Moscow State Institute of International Relations (University) of the Ministry of Foreign Affairs of Russia
}

\begin{abstract}
Social media analysis is widely used in economics, sociology, in medical studies of spreading infectious diseases and in forensic science to stop terrorist networks and drug proliferation. Social media analysis is also used in political sphere. Opinion leaders are increasingly participating in social media. The Internet is a reflection of the real world, it has the same laws as in real society. The ruling elite controls the media and social media as well as it controls the means of production. The article addresses the role of social networks in the foreign and military policies of states and other actors. The spread of leadership networks is at its early state. The potential of this Internet resource format is enormous. There is every reason to assume that economic crisis makes such resources even more popular. During economic crisis many people are left alone with their problems by their government and they are even more motivated to social cooperation and mutual assistance in social networks to receive valuable information, attention and support from the outside.
\end{abstract}

Key words: soft power, international environment, information and cognitive means of confrontation, social networks, leadership networks, local human civilization, military-political environment, ideology.

\footnotetext{
Al recent revolutions have taken place with the use of social networks, monitoring them to track the popular mood can reveale the sustainability of the ruling regime.
}

Social networks emerged as a social structure that brings together individuals and organizations. The term itself was introduced in 1954 by the English anthropologist D. Barnes, who developed an approach invented in the 1930s in America to the study of relationships between people by means of sociograms. This approach deals with visual diagrams in which individuals are represented in the form of dots and connections 
between them. By the 1970s a complex of sociological and mathematical methods of research had finally formed, which form the scientific foundation of modern social network analysis (SNA) ${ }^{1}$.

The political value of social networks as tools of soft power depends on commitment of the ruling elite to the dominant ideology. If there is a rejection of ideology on the elite level the efficiency of various tools of national soft power will be low. It would be naive to believe that ideology exists independently from elites and that the means of ideological influence, such as social media, exist independently.

The concept of ensuring the security of the Western military-political coalition, formulated in recent years by Donald Trump is correctly interpreted by Russian Deputy Foreign Minister Sergey Ryabkov as a 'concept of total military dominance in all spheres' (Ryabkov 2019) with special emphasis placed on technological, information and cognitive superiority of the United States. In this sense, the Internet in general and social networks in particular have become an extremely important systemic tool not only for the US foreign policy, but also for the US military policy, which is strongly oriented towards achieving political results through domestic political destabilization of opponents (Strategicheskoe sderzhivanie... 2019: 511-566).

The purpose of this article is to identify the current practices to spread influence over policy decisions via the Internet and social media. Methodologically the article is based on neo-Marxism. The authors proceed from the Gramshian idea that the dominant class has not only a monopoly on the means of material production, but also on the means of producing meanings and ideas. Using this monopoly, the dominant class establishes cultural hegemony and ensures the sustainability of its legitimacy. Accordingly, undermining cultural hegemony from outside by means of social media could ruine the legitimacy of the ruling regime. Specific ways of undermining legitimacy in authoritarian states are widely known through Gene Sharp 's (1993) work, and the use of social media for political power purposes can be read in detail in Michael Erbschloe's (2016) writings.

\section{The role of network resources in soft power}

It is generally accepted that ideology is «a set of ideas, beliefs, perceptions, myths, etc., reflecting the social needs and aspirations of individuals, groups, classes, and society as a whole» (Sovremennaya politicheskaya mysl'... 2016: 54). Karl Marx stated that "the ideas of the dominant class in all epochs are dominant', and, that 'the class having control over the means of production... controls the means of spiritual production» (Sovremennaya politicheskaya mysl'... 2016: 55), i.e. the media and social networks if we use modern terms. In the modern version, this means that the ruling elite controls

\footnotetext{
1 Belousov V. Social'nye Internet-seti kak politicheskoe oruzhie i instrument konkurentnoj bor'by [Social Internet Networks as a Political Weapon and Tool of Competition]. "Kapital strany" 18.04.2011 URL: http://kapital-rus.ru/articles/article/socialnye_internet-seti_kak_politicheskoe_oruzhie_i_instrument_konkurentnoj/ (accessed 28.02.2020) (In Russian)
} 
the media and social networks as well as how it controls the means of production, which should not be forgotten when talking about 'independent social' media and Internet networks.

Ideological and cognitive dimentions of power became intreasingly important tool of foreign and military policy in the $20^{\text {th }}$ century. There are two fundamentally different positions: the position of the USSR (Khrushchev 2019) and later Russia that for a long time underestimated the importance of information and cognitive factors, and, on the contrary, the position of the United States and the Western military-political coalition as a whole, where these means were given priority ${ }^{2}$. As Deputy Minister of Foreign Affairs of Russia Sergey Ryabkov noted, «There is no doubt that the Americans managed to introduce into the political consciousness of the elites and leadership of almost all their allies a distorted and malicious version of what is happening' in the world» (Ryabkov 2019: 26). Moreover, it is information and cognitive means that are at the center of the system, which became known as 'The Power to Force' (Gompert, Binnendijk 2016: 42).

Until the second decade of the new century this difference in attitude towards ideology, information and cognitive means of politics led to the fact that in the confrontation of various actors in the world Russia was qualitatively inferior to the West, which acted freely both in the international sphere and in the domestic sphere of our country. The reason is that Russia voluntarily abandoned not only the system of values as a national ideology, but also dismantled and disorganized state and social institutions, 'means of ideological production', which ensured the implementation of the system of national interests and values united in ideology.

From the last quarter of the $20^{\text {th }}$ century in the USSR and later in Russia there was a slow and inconsistent process of reassessment of communist political-ideological attitudes, which led to the loss of ideological leadership, when since the second half of the 1950s and in the 1980s the Communist party tried to painfully incorporate new ideas into 'old fur', to abandon Leninism-Stalinism in favor of the concept of 'developed socialism' (Sovremennaya mezhdunarodnaya... 2015: 317-450). The loss of ideological leadership that occurred over time in the USSR was equivalent to the rejection of effective cognitive and ideological means of struggle, which in fact meant voluntary disarmament. This became very well known today from the documents on preparation of ideological statements of the country leaders and the Communist Party (Skazka o poteryannom... 2011: 461-665).

Later, in the second half of the 1980s, the chief ideologist of the Communist Party, Alexander Yakovlev (who eventually acknowledged that his goal was to destroy communism), declared 'deideologization of ideology', which in fact meant total renunciation of ideological autonomy, actual submission to foreign will and ideas, programmed a foreign policy dependence on the West for years to come («Perekhodnyj period»... 2019).

\footnotetext{
2 The National Military Strategy of the United States of America. 2015. Washington. P. I; 17.
} 
Over the last 20 years US foreign policy has seen a qualitative shift in the use of information and cognitive tools - from the concept of 'soft power' (the attractiveness of the West 's system of values and interests) to the concept of 'power to coerce' (Publichnaya diplomatiya... 2017). At the same time, the role of network resources has proved decisive - it is possible to 'persuade' through public media, but real coercion can be achieved only through social networks, when it is possible to blackmail individual members of the ruling elite or entire social groups.

Soft power masks its coercieve characteristics in every way, preferring to show signs of 'attractiveness' on the surface, while 'power to coerce' uses all instruments of power - from diplomatic to cyber and openly military.

The main objective of ideological and cognitive means of power has changed in many ways: if soft power was mainly aimed at the policy of opponents, their values and interests (manifested in relation to the USSR under Michael Gorbachev), the main objective of power to coerce is destoying elites and breaking the system of values of population, which is exemplified in case of Russia 's ruling elite after 2014 ( Perekhodnyj period»... 2019).

Information and cognitive means of power have now become the most important instruments of force, and soft power became part of the power to coerce. This new policy was even given a special name 'the policy of new public diplomacy', where 'new' means a synthesis of attraction and coercion (Publichnaya diplomatiya... 2017).

At the same time, it should be noted that such political practices began to develop even before Barack Obama's and Donald Trump's administrations came to power. The theory and practice of 'nonviolent resistance' became the norm thanks to the work of Harvard University professor Gene Sharp (Sharp 1993: 80). Over time he became known as "Clausewitz of nonviolent warfare». Unlike Mahatma Gandhi and Martin Luther King, Gene Sharp suggests that politicians should use his methods of civil disobedience to seize power (Sotsial'nye seti... 2012).

'Coercive non-violence' proved to be effective in past decades. There was 'Bulldozer revolution' in Serbia in 2000, 'Rose revolution' in Georgia in 2003, 'Orange Revolution' in Ukraine in 2004, 'Cedar Revolution' in Lebanon in 2005 leading to Syrian withdrawal, and 'Tulip revolution' in Kyrgyzstan in 2005, repeated in 2010 to remove Kurmanbek Bakiyev. Two years later, the Obama administration relied on indirect participation in regime change in Tunisia (January 2011) and Egypt (February 2011).

In addition, Algeria (2010-2011), Yemen (2011), Syria, Bahrain, Jordan and Libya were suffering from 'non-violent resistance' during these years. To a lesser extent, protest potential was evident in Morocco, Saudi Arabia, Lebanon, Iraq, Oman, Kuwait, Mauritania, Sudan, Somalia, Western Sahara and Djibouti.

This broad list of countries brings closer the realization of the long-awaited US goal to rebuild geopolitically entire regions, especially the 'Greater Middle East', by reinforcing the legitimacy of pro-American elites in the face of the weakening global position of the United States and, in particular, the dollar. This means that the second decade of the new century is fundamentally different from previous periods of inter- 
national relations in the ways power is used. Information and cognitive warefare is increasingly becoming the dominant tool of political rivalry among nations («Perekhodnyj period»... 2019).

The ultimate goal of any coercieve foreign policy strategy is to preserve one's own domestic political stability and to destroy someone else's. This goal is based on two principles:

First, the strength and stability of the state are based on the cooperation of the government and citizens and legitimacy of the government. As soon as the legitimacy is questioned (as in December 1916 - January 1917 in Russia), domestic political stability quickly turns into fiction;

Secondly, stability is based on communication and dialogue between government and society. Once such communication disappears or becomes one-sided, unilateral actions very quickly become destructive. An example of the elimination of such dialogue is the termination of negotiations in St. Daniel Monastery between representatives of the Supreme Council of Russia and the President, which quickly (in less than 24 hours) led to an armed clash (Russkii Put'... 1998).

\section{Social media and security}

In assessing the use of social media for political purposes one shall take into account:

- the real state capabilities needed for defence and security are part of national information capabilities;

- business opportunities and actual owners of Internet resources and social networks;

- the actual capabilities and resources of social networks - individual citizens. One should take into account that the use of both private and public resources is inevitable for political purposes. In 2017-2019, in the USA and other countries, accusing Russia of interfering in elections (in the USA, France, Germany, Serbia, etc.), actually recognized the possibility and even inevitable use of public and private resources for information and cognitive confrontation.

Thus, speaking about the use of social networks, we should not ignore the role of the state and business, as well as coalition allies (who actively participated in such a company in 2014-2019). A pattern of behaviour is proposed although it may change in some details (Sotsial'nye seti... 2012):

- A virtual opposition is created, which starts information cascades about its political activity. These cascades are amplified by various 'activists', who are 'concerned' about the problem. At the same time, it does not matter what problem it is - environmental degradation or the use of chemical weapons - the main point is that this problem is anti-government. The number of participants who cooperate on social networks is not critical. A series of endless comments and likes ultimately leads to that this problem becomes recognizable and turns into a threat to the existing regime. 
This campaign should achieve its apogee at some significant political event: elections, a landmark anniversary, an expected event in the life of the country or abroad, when society and the media become as active as possible. By this time, the number of participants in the network discussions should reach some critical mass (which should not necessarily be huge), capable - most importantly - to demonstrate a protest. Such demonstrations can be well motivated, moreover, in some cases extremist and hooligan groups hired for a particular reason are allowed. The entire mechanism is put into operation after the announcement of the results of the elections, which usually do not meet the demands of the opposition leader.

The next important stage, when 'global public opinion' is mobilized in the statements of political and public figures in the media, social networks and international organizations about 'violations of democratic procedures', use of force and even weapons, 'genocide', etc., violations of international norms, which should entail assessments and sanctions by the United States and Western institutions (and in some cases the United Nations). These demands should destabilize the situation in the country, forcing the Government to make concessions to the opposition. At the same time, they are often reminded of the fate of Ceausescu, Milosevic and other leaders who 'during the time failed to make concessions to the opposition'.

Over time the concern about coercive use of information and communication technologies in international relations was reflected in the national security strategy of Russia ${ }^{3}$ when systemic security is achieved by oppising the systemic power policy of the United States, called 'the power to coerce'. Social networks created to improve communication between people have now become a new type of weapon.

\section{War without war}

The distinctive feature of this new type of weapon is, above all, that it is not always or universally recognized as a weapon because it is not a conventional weapon, although decisions on its use are taken at the highest political level and the consequences of such decisions are far-reaching. Thus, the ban on the use of the Linkedin network in Russia, adopted on November 17, 2016, led to an official protest by the U.S. Embassy ${ }^{4}$.

It must be recognized that deviding means of armed struggle into 'shooting' and 'supporting', has not been relevant for a long time. In practice, it turns out that 'nonfiring' means of armed struggle are both more dangerous and more effective than traditional means of fire. Division into 'lethal' and 'non-lethal' weapons is often a convenient cover for direct military intervention in the affairs of other states.

\footnotetext{
${ }^{3}$ Decree of the President of the Russian Federation" on the national security Strategy of the Russian Federation. No. 683 of December 31, 2015. Section II. Points 21, 22, 43, 47, 82, 113

4 SShA prizyvayut RF razblokirovat' Linkedln i peresmotret' zakon o dannykh [The United States urges Russia to unlock Linkedln and to Revise the Law on Data]. 2016. BBC News, 18.11.2016. URL: http://www.bbc.com/russian/news-38023440 (accesse 28.02.2020)
} 
In addition, in recent decades, military art has undergone major systemic changes. In the United States, for example, modern military strategy recognizes the 'subordination' of military means to the use of other non-military means of influence in politics: 'Our military (capabilities) support diplomatic, information and economic actions designed to ensure our national interests ${ }^{\prime 5}$. Military means contribute to improving the effectiveness of the use of other means of force, not vice versa.

In the 21 st century information security, especially through social networks, has become the most important factor of systemic security. Today it is already difficult, and often impossible, to define the line between the state of 'peace' and 'war' - states fight using numerous means and methods, but at the same time participate in negotiations, trade and even exchange visits. A typical example is the conflict in Ukraine, where thousands of citizens are killed, and gas is traded and negotiated in parallel.

In "war without war" social networks have become an important factor not only of military success, but also of security, peace and stability. The category 'war' is displaced by the category 'operation'. The essence of the social phenomenon does not change from this. These are network-centric wars, network approaches to fighting (Rossiya $\mathrm{v}$ zerkale... 2012: 180). The 'Network' in a broad sense includes simultaneously different political and social components. They can be combat units, communication system, information support, formation of public opinion, diplomatic measures, social processes, intelligence and counterintelligence, ethnopsychology, religious and collective psychology, economic support, academic science, technical innovations (Aktual'nye problemy... 2017).

The Network has become inextricably linked to politics and armed struggle. Especially when conditions have developed for a network-centric war, in which subjective, cognitive and even irrational factors play a huge role. At the same time, the main feature of the network-centric war, which inevitably affects the nature of the modern international situation, is that it has no beginning and end, and is carried out constantly. At the same time, existing 'cumbersome state structures and international organizations', according to experts, 'are unable to respond quickly to the challenges of time' (McConnell 2016: 138). This means that the active and uncontrolled introduction of the 'network' by the world community represents the inevitable deprivation of any independence, sovereignty and subjectivity of countries, peoples, armies and governments of the world, and their transformation into tightly managed, programmed mechanisms. In this sense, the world, according to a number of researchers, is in constant information confrontation, which is a very broad concept, deeper in content than information war (Rossiya v zerkale... 2012). This confrontation takes place at the civilizational level between local human civilizations (LHCs), when victory or defeat is seen as an uncompromising result of such a battle, expressed in the loss of sovereignty, national identity, territories and the disappearance of nations themselves (Tret'ya mirovaya...2015).

\footnotetext{
5 The National Military Strategy of the United States of America. Washington: GPO, 2015. June. The United States Military's Contribution to National Security. 2015. June. P. 5
} 


\section{Using leadership networks}

The current analysis of social networks focuses on the structure of their relationships within a community or working group. Network analysis helps model structural interactions between social units: people, collectives, organizations (Strategicheskoe sderzhivanie... 2019). Among other advantages, the network approach allows data to be operated at different levels of research, from the micro to the macro level, ensuring data continuity when smaller units are combined into large ones without losing information. Social media analysis is today widely used in economics and governance to analyse markets, in sociology, in medicine, for example, in exploring the ways in which infectious diseases spread and in forensics to combat terrorist networks and the spread of drugs.

Opinion leaders are increasingly present on virtual social networks. The Internet is the reflection of the real world, it follows the same laws as the real society. Most politicians, writers, scientists, journalists have blogs.

Social media is widely used by country leaders, especially during election campaigns. In the United States, the last two presidents, Barack Obama and Donald Trump, owe much to an unprecedented online campaign, primarily through their own personal leadership networks and social networks through which they communicated with voters.

Leadership networks can be social networks formed around a personal or corporate interactive resource (Fig.1), or social networks built around several resources - attention nodes.

In the first case, the personal or corporate site functions as a network interface. Users register on it and are able to create their own blogs. They communicate with the owner of the site and with each other, participate in joint collective social actions. Such leadership networks will become a new generation of personal resources, after websites and blogs on social networks. Unlike regular websites, blogs in networks and standard blogs, a new kind of leadership resources creates a personal social network around it. This network includes members of the target audience for the resource owner. The formation of such a network ensures stable interactive communication with visitors and the ability to have a constant influence on their consumer and social behavior.

Compared to personal sites and stand-up blogs, leadership resources have higher interactivity, more effectively shape the communication environment, give visitors better opportunities for self-expression. Unlike blogs in conventional networks, they exist in a specially created favorable environment where it is impossible to get lost or be compromised by an inadequate network environment; and give their authors the opportunity to monetize the attention of visitors ${ }^{6}$. 


\section{Leadership network built around personal resource}

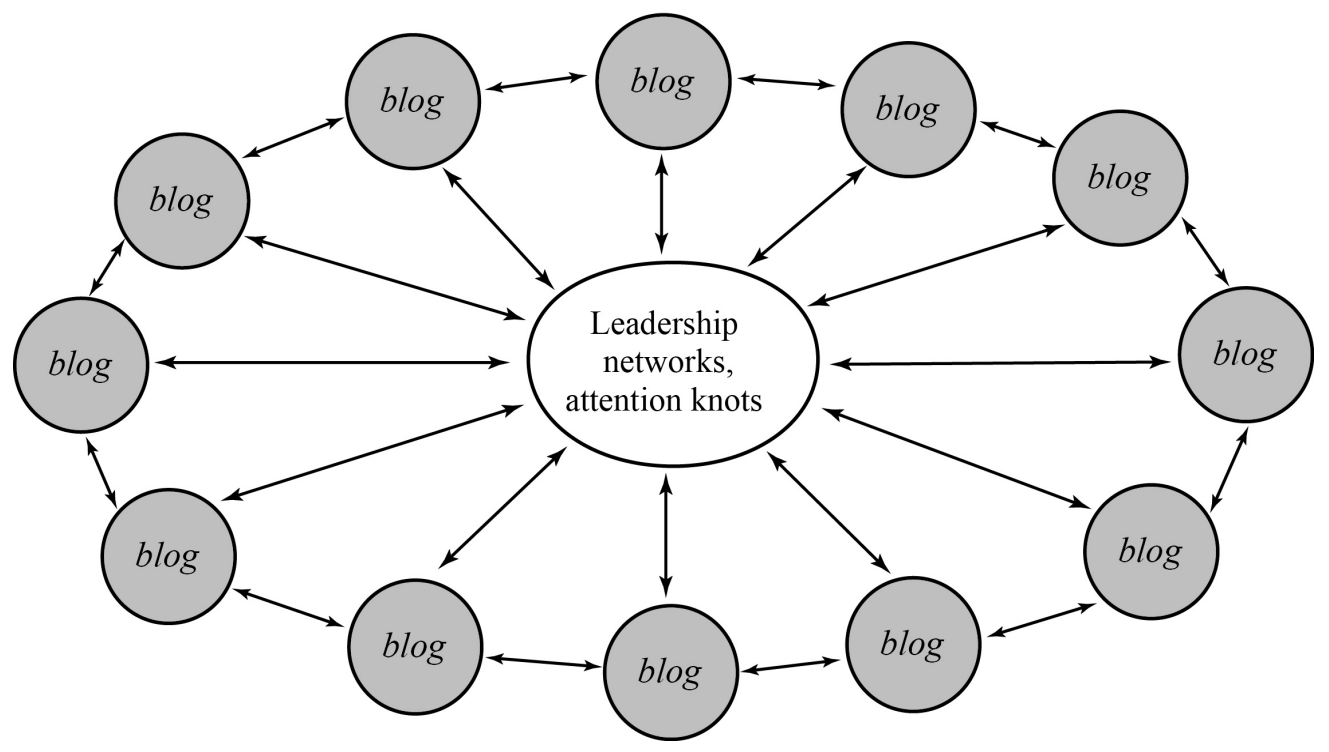

Fig. 1. Social networks formed around a personal or corporate interactive resource ${ }^{7}$

The organizers of leadership networks should help their agents make their own attractive resource. The company's task is to create leadership resources that support its high technological and creative level. Leaders, in order to make their resource popular, must constantly communicate online with users. Without help, this task is not feasible. To ensure its solution, continuous content support of leadership resources is provided by the organizing companies. Centralized support is much more efficient and cost-effective than individual personal assistants. Within the framework of social and network companies, teams of content managers can be created, working in close contact with owners of leadership resources. They can provide operational support for communications of a significant number of leadership resources on the network (Strategicheskoe sderzhivanie... 2019).

The development and implementation of distributed information processing systems and tools are provided by world's largest companies (IBM, Informix, Lotus, Microsoft, Oracle, etc.). The reason for this increased attention to such applications is that the rapid development of the Internet today is largely provided by means that extract useful information from already accumulated distributed databases. From this point of view, numerous large databases acquire new qualities: they become closer to the consumer and gain 'feedback'. Now many companies and shops have their own Inter-

\footnotetext{
7 Белоусов В. Социальные интернет-сети как политическое оружие и инструмент конкурентной борьбы. Электронный ресурс: «Капитал страны». 18.04.2011. http://kapital-rus.ru/articles/article/socialnye_internet-seti_kak_ politicheskoe_oruzhie_i_instrument_konkurentnoj/ (accessed 28.02.2020)
} 
net pages, where the buyer can view the name of goods, prices, see the image of goods, make an order and immediately pay for it by credit card.

Social networks are formed around leaders, whose key resource is content. Social and state contradictions are in many ways expresions of more powerful, civilizationcultural, contradictions. Absolute majority of information resources are in the hands of Western civilization.

In order to effectively counter the spread of Western influence through the Internet and reduce the vulnerability of the political systems, it is necessary to develop our own leadership networks based on Russian language, Russian culture, support for pro-Russian communities and groups abroad, work with data, collect and defend it.

\section{About the authors:}

Alexey I. Podberezkin - Doctor of History, Professor of World and National History Chair, Director of the Center for Military and Political Studies, MGIMO-University. 76, Prospect Vernadskogo, Moscow, 119454, Russia.E-mail: vestnik@mgimo.ru.

Olga A. Podberezkina (corresponding author) - Researcher at the Center for Post-Soviet Studies at the Institute for International Studies MGIMO-University. 76, Prospect Vernadskogo, Moscow, 119454, Russia. E-mail: podberezkina.olga@yandex.ru.

\section{Conflict of interests:}

The authors declare absence of conflict of interests.

\section{Лидерские сети как инструмент} принуждения в мировой политике

А.И. Подберёзкин, О.А. Подберёзкина DOI 10.24833/2071-8160-2020-1-70-117-128

Московский государственный институт международных отношений (университет) МИД России

Аннотация: Анализ социальных сетей широко применяется в экономике, социологии, в медицине, например, при изучении путей распространения инфекционных заболеваний и в криминалистике для борьбы с террористическими сетями и распростране- 
нием наркотиков. Анализ социальных сетей используется и в политической сфере. Интернет - отражение реального мира, в нём действуют те же законы, что и в реальном социуме. Правящая элита контролирует СМИ и социальные сети так же как она контролирует средства производства. В статье рассматривается вопрос о роли социальных сетей во внешней и военной политике государств и других акторов. Методологически статья основана на грамшианской идее о культурной гегемонии правящего класса как основе легитимности политического режима. Дж. Шарп показал, как можно подорвать легитимность авторитарного режима через ненасильственное сопротивление. Статья показывает, какую роль в этом играют социальные сети и как через них легитимность политического режима подрывают извне. Поэтому информационное, культурное, экономическое влияние следует рассматривать как форму войны.

Распространение лидерских сетей только начинается. Потенциал этого формата интернет-ресурсов огромен. Экономический кризис делает такие ресурсы ещё более востребованными. В тяжёлых условиях кризиса люди, оставленные государством наедине со своими проблемами, в ещё большей степени мотивированы на социальную кооперацию и взаимопомощь в сети, на получение ценной информации, внимания и поддержки со стороны.

Ключевые слова: «мягкая сила», международная обстановка, информационно-когнитивные средства борьбы, социальные сети, лидерские сети, локальная человеческая цивилизация, военно-политическая обстановка, идеология.

\section{Об авторах:}

Алексей Иванович Подберёзкин - доктор исторических наук, профессор кафедры всемирной и отечественной истории, директор Центра военно-политических исследований МГИМО МИД России. 119454, г. Москва, проспект Вернадского, д. 76.

E-mail: vestnik@mgimo.ru.

Ольга Алексеевна Подберёзкина - кандидат политических наук, научный сотрудник Центра постсоветских исследований ИМИ МГИМО МИД России. 119454, г. Москва, проспект Вернадского, д. 76. E-mail: vestnik@mgimo.ru.

\section{Конфликт интересов:}

Авторы заявляют об отсутствии конфликта интересов.

\section{References:}

Gompert D., Binnendijk H. 2016. The Power to Coerce. Coutering Adversarie Without Going to War. RAND Corporation.

Sharp G. 1993. From Dictatorship to Democracy. A Conceptual Framework for Liberation. The Albert Einstein Institution.

\section{3 strategii voiny [33 Strategies of War]. 2016. Moscow: RIPOLL. (In Russian)}

Aktual'nye problemy protivodeistviya terrorizmu i ekstremizmu: tematicheskii sbornik [Actual Problems of Counteraction to Terrorism and Extremism: a Thematic Collection]. 2017. Ed. by V.V. Krasinsky. Moscow. 221 p. (In Russian)

Khrushchev S. 2019. Nikita Hrushchyov. Rozhdenie sverhderzhavy [Nukita Khrushchev. The Birth of a Superpower]. Moscow: Veche. 608 p. (In Russian)

McConnell B. 2016. Setevoe soobshchestvo i rol' gosudarstva [Network community and the role of the state]. Russia in Global Politics. No. 2. P. 138. (In Russian) 
Publichnaya diplomatiya: Teoriya i praktika [Public diplomacy: Theory and practice]. 2017. Ed. by M.M. Lebedeva. Moscow: Aspect Press. (In Russian)

«Perekhodnyj period» razvitiya voenno-silovoj paradigmy (2019-2025 gg.) ["Transition period" of the development of the military-power paradigm (2019-2025)]. Obozrevatel. 2019. No. 4. P. 5-20. (In Russian)

Rossiya v zerkale uprazhnenii NATO nad Ukrainoi [Russia in the Mirror of NATO Exercises over Ukraine]. 2012. Diplomacy. No. 4. (In Russian)

Russkii Put' [Russian Way]. 1998. Moscow: IA "Observer". 592 p. (In Russian)

Ryabkov S. 2019. Frank conversation about war and peace. International affairs. No. 1. P. 26. URL: https://interaffairs.ru/news/show/21714 (In Russian) (accessed 28.02.2020)

Skazka o poteryannom vremeni. Pochemu Brezhnev ne smog stat' Putinym [A Tale of Lost Time. Why Brezhnev Could Not Become Putin]. 2011. Moscow: OLMA Media Group. (In Russian)

Sotsial'nye seti kak innovatsionnyi mekhanizm «myagkogo» vozdeistviya i upravleniya massovym soznaniem [Social networks as an innovative mechanism for "soft" influence and management of mass consciousness]. 2012. Politics and society. No. 1. P. 65-75. (In Russian)

Sovremennaya mezhdunarodnaya obstanovka: civilizacii, ideologii, elity [Modern International Environment: Civilizations, Ideologies, Elites]. 2015. Moscow: MGIMO-University. (In Russian)

Sovremennaya politicheskaya mysl' (XX-XXI). Politicheskaya teoriya i mezhdunarodnye otnosheniya [Modern Political Thought (20-21st century). Political Theory and International Relations]. 2016. Moscow: Aspect Press. (In Russian)

Strategicheskoe sderzhivanie: novyj trend i vybor rossijskoj politiki [Strategic Deterrence: a New Trend and the Choice of Russian Policy] 2019. Moscow: MGIMO University. 656 p. (In Russian)

Tret'ya mirovaya voina protiv Rossii: vvedenie $\mathrm{k}$ issledovaniyu [The Third World War against Russia: an Introduction to the Study]. 2015. Moscow: MGIMO University. P. 13-24. (In Russian) 